\title{
Effect of dietary Sargassum wightii and its fucoidan-rich extract on growth, immunity, disease resistance and antimicrobial peptide gene expression in Labeo rohita
}

\author{
Adnan Hussain Gora ${ }^{D} \cdot$ Narottam Prasad Sahu - Sujata Sahoo • \\ Saima Rehman • Showkat Ahmad Dar • Irshad Ahmad • \\ Deepak Agarwal
}

Received: 26 January 2018/Accepted: 19 April 2018/Published online: 2 May 2018

(C) The Author(s) 2018

\begin{abstract}
This work aimed to appraise growth performance, immune responsiveness, bacterial disease resistance and mRNA expression of two antimicrobial peptides in Labeo rohita fingerlings fed diets supplemented with seaweed Sargassum wightii and its fucoidan-rich extract. Two hundred and twenty-five fingerlings were divided into five experimental groups in triplicates, each replicate having 15 fish in a $90-\mathrm{L}$ tank. Different groups were fed with isonitrogenous (35\% crude protein) and isoenergetic $(1408.16 \mathrm{~kJ} / 100 \mathrm{~g})$ diets containing either 0\% fucoidan-rich seaweed extract (FRSE), 1\% FRSE, 2\% FRSE, 3\% seaweed powder and $6 \%$ seaweed powder for 60 days. Partial nucleotide sequences of the antimicrobial peptides, hepcidin and defensin, were characterized in Labeo rohita fingerlings, and gene expression in the different tissues of experimental fish was studied. The fish-fed FRSE-supplemented diets showed significant increase $(P<0.05)$ in the mRNA expression of antimicrobial peptides in liver, skin and intestine tissues. Bacterial challenge study using Aeromonas hydrophila showed higher survival in the FRSE-fed groups. Fish-fed FRSE-supplemented diets also showed better non-specific immune response (NBT reduction, serum lysozyme activity, serum albumin: globulin ratio and phagocytic activity) in pre-challenge and post-challenge periods. No significant difference was observed in the growth performance in the different experimental groups. The study indicates that although dietary FRSE is a potential immunostimulant in Labeo rohita fingerlings, it does not improve growth performance.
\end{abstract}

Keywords Antimicrobial peptides $\cdot$ Nutraceutical $\cdot$ Immunomodulation $\cdot$ Fish

\author{
A. H. Gora · S. Rehman \\ Division of Marine Biotechnology, Chennai Research Centre of ICAR-Central Marine Fisheries Research Institute, Chennai, \\ India \\ A. H. Gora ( $\square)$ \\ Chennai Research Centre of ICAR-Central Marine Fisheries Research Institute, 75, Santhome High Road, R.A. Puram, \\ Chennai 600028, India \\ e-mail: goraadnan@gmail.com \\ N. P. Sahu - S. Sahoo - S. A. Dar \\ Division of Fish Nutrition, Biochemistry and Physiology, Central Institute of Fisheries Education, Mumbai, India \\ I. Ahmad \\ Division of Aquaculture, Central Institute of Fisheries Education, Mumbai, India \\ D. Agarwal \\ Division of Fish Genetics and Biotechnology, Central Institute of Fisheries Education, Mumbai, India
}




\section{Introduction}

Disease outbreak is one of the main limiting factors for sustainable aquaculture production. Tropical countries suffer proportionally greater losses during disease outbreaks (Robar et al. 2010). Motile aeromonas septicaemia, caused by Aeromonas hydrophila (Plumb 1999), is one of the most deadly bacterial infections encountered in aquaculture practices. The disease is highly contagious among the fish and results in high mortalities within few days (Roberts 1993) with ulceration, exophthalmia and abdominal distension as symptoms (Camus et al. 1998). There is no commercially available vaccine that is effective against all strains of A. hydrophila (Poobalane et al. 2008). Hence, various chemotherapeutants may be used for prevention of this disease in aquaculture. However, their use does not come without the risk of antibiotic resistance in pathogenic bacteria (Huys et al. 2000), tissue antibiotic residues (Angulo et al. 2004), aquatic environment pollution (Hektoen et al. 1995) and transfer of resistance to human pathogenic bacteria (Sørum 2006). Therefore, novel strategies to control bacterial infections are needed (Defoirdt et al. 2011). These alternative measures involve the use of natural bioactive compounds that stimulate the immune system of fish. Antimicrobial peptides (AMPs) are components of the innate immune system of fish that provide protection against bacteria, fungi and virus (Cuesta et al. 2011; Zasloff 2002). Most antimicrobial peptides prevent the colonization of pathogens by lytic or ionophoric mechanism (Smith et al. 2010). Two important and wellknown classes of antimicrobial peptides are defensins and hepcidins. Defensins and hepcidins characterized so far in fishes have shown strong antimicrobial activity against pathogens (Falco et al. 2008; Xu and Faisal 2010; Álvarez et al. 2014; Xu et al. 2014). Furthermore, these antimicrobial peptides exhibit increased expression at the transcriptomic level in fishes fed with dietary immunostimulants (Marel et al. 2012; Gong et al. 2014).

An immunostimulant is a chemical, drug, or stressor that enhances the immune response by interacting directly with cells of the system activating them. Non-specific immunostimulants act irrespective of antigenic specificity to augment immune response and stimulate components of the immune system. Seaweeds are cheap and easily available resource of bioactive compounds that can be used as immunostimulants in aquaculture (Deivasigamani and Subramanian 2016). Sargassum, a genus of brown seaweed (Phaeophyceae), contains a conglomerate of bioactive compounds such as steroids, alkaloids, phenolic compounds, saponins and flavonoids rendering it a number of different bioactive properties (Arunkumar et al. 2005; Zubia and Deslandes 2008). Sargassum wightii also contains fucoidan, a water-soluble, sulphated fibrous polysaccharide. Fucoidan is bestowed with many biological properties that include immunostimulation (Kitikiew et al. 2013; Prabu et al. 2016) disease resistance (Chotigeat et al. 2004; Immanuel et al. 2012), growth stimulation in shrimps (Traifalgar et al. 2010) and finfish (Tuller et al. 2014; Prabu et al. 2016). The effect of dietary Sargassum wightii and its fucoidan-rich extract on the immuno-physiological responses and growth performance of Indian major carps has not been studied in detail. In this context, the present work was designed with the objective to study the dietary effects of Sargassum wightii and its fucoidan-rich seaweed extract (FRSE) on the non-specific immune status, gene expression level of $\beta$-defensin 1 and hepcidin and survival of $L$. rohita fingerlings challenged with A. hydrophila.

\section{Materials and methods}

Preparation of fucoidan-rich seaweed extract

The brown seaweed, Sargassum wightii, required for the experiment was collected from Mandapam, Tamil Nadu (India) with the help of fishermen. Seaweeds were subsequently sorted out, washed thoroughly with water, shade dried and finally ground into fine powder. This powder was used for feed preparation and extraction of crude fucoidan. The crude FRSE was obtained from seaweed powder by the alcohol-hot water method of Prabu et al. (2016). To quantify the fucoidan content in crude FRSE, it was dialyzed in a cellulose tubing having molecular weight cut off of 5000. The L-Fucose content in the dialyzed sample was calculated according to Dubois et al. (1956) and from this the fucoidan content was obtained by multiplying the fucose values with 1.75 . 
Experimental fish and diets

Three hundred five fingerlings of $L$. rohita with an average weight of $8.852 \pm 0.2 \mathrm{~g}$ were procured from R.A. Farm, Mumbai, India. Fish were acclimatized for 15 days in laboratory condition in $1000 \mathrm{~L}$ tanks at $30{ }^{\circ} \mathrm{C}$, under continuous aeration before starting the experiment. From this stock, eighty fingerlings were used for determination $\mathrm{LD}_{50}$ prior to bacterial challenge study. Two hundred and twenty-five fingerlings were used for the feeding experiment and bacterial challenge study. Semipurified ingredients were used for feed formulation (Table 1). Five experimental diets (crude protein and lipid levels at 35 and $8 \%$, respectively) were fed to different experimental groups. Continuous aeration was provided to all the tubs throughout the experimental period. The fish were fed to satiation daily at $10.00 \mathrm{~h}$ in the morning and $18.00 \mathrm{~h}$ in the evening under normal light regime.

Experimental design and in vivo study

Two hundred and twenty-five fingerlings were randomly transferred to plastic tanks of 100 L capacity with 15 fingerlings per tank in triplicates following a completely randomized design (CRD). The first group was maintained as control in which fish were given no dietary FRSE or seaweed. In second and third groups, fish were given 1 and 2\% dietary FRSE, respectively. In the fourth and fifth groups, the fish were provided finely ground seaweed powder at the levels of 3 and $6 \%$ of the diet, respectively. After 60 days of feeding trial, five fish from each replicate was selected for blood collection (pre-challenge) by caudal vein puncture using a 1-ml 26G syringe. For analysis, fresh blood was used. For obtaining the serum, part of the blood was allowed to stand for $4 \mathrm{~h}$ and then centrifuged at $1006 \times g$ for $5 \mathrm{~min}$. The straw color serum was pipetted out as supernatant and stored at $-80{ }^{\circ} \mathrm{C}$. These fish were killed and liver, gill, spleen, kidney, intestine and skin tissues were

Table 1 Composition of experimental diets $(\mathrm{g} \%)$

\begin{tabular}{|c|c|c|c|c|c|}
\hline Ingredients & Control $(C)$ & $\begin{array}{l}1 \% \text { fucoidan } \\
(\mathrm{T} 1 \mathrm{~F})\end{array}$ & $\begin{array}{l}2 \% \text { fucoidan } \\
\text { (T2F) }\end{array}$ & $\begin{array}{l}3 \% \text { dry seaweed } \\
\text { (T3S) }\end{array}$ & $\begin{array}{l}6 \% \text { dry seaweed } \\
\text { (T4S) }\end{array}$ \\
\hline Casein & 30 & 30 & 30 & 30 & 30 \\
\hline Gelatin & 9.5 & 9.5 & 9.5 & 9.5 & 9.5 \\
\hline Starch & 17 & 17 & 17 & 17 & 17 \\
\hline Dextrin & 20 & 20 & 20 & 20 & 20 \\
\hline Cellulose & 11 & 10 & 9 & 8 & 5 \\
\hline Cod liver oil & 4 & 4 & 4 & 4 & 4 \\
\hline Sunflower oil & 4 & 4 & 4 & 4 & 4 \\
\hline Vit-min premix & 2 & 2 & 2 & 2 & 2 \\
\hline Carboxymethyl cellulose & 2 & 2 & 2 & 2 & 2 \\
\hline Choline chloride & 0.4 & 0.4 & 0.4 & 0.4 & 0.4 \\
\hline $\begin{array}{l}\text { Butylated hydroxy } \\
\text { toluene }\end{array}$ & 0.1 & 0.1 & 0.1 & 0.1 & 0.1 \\
\hline FRSE/seaweed powder & 0 & 1 & 2 & 3 & 6 \\
\hline Total & 100 & 100 & 100 & 100 & 100 \\
\hline \multicolumn{6}{|l|}{ Proximate analysis ( $\mathrm{g} \%$ ) } \\
\hline Moisture & $7.6 \pm 0.30$ & $7.2 \pm 0.19$ & $8.0 \pm 0.10$ & $7.7 \pm 0.10$ & $7.9 \pm 0.15$ \\
\hline Crude protein & $35.7 \pm 0.12$ & $34.5 \pm 0.03$ & $34.9 \pm 0.08$ & $35.0 \pm 0.1$ & $35.6 \pm 0.15$ \\
\hline Crude lipid & $7.9 \pm 0.03$ & $8.1 \pm 0.12$ & $7.8 \pm 0.27$ & $7.7 \pm 0.02$ & $8.0 \pm 0.19$ \\
\hline Crude fiber & $13.1 \pm 0.2$ & $12.8 \pm 0.56$ & $13.5 \pm 0.34$ & $12.6 \pm 1.8$ & $13.6 \pm 2.1$ \\
\hline Ash & $9.3 \pm 0.7$ & $9.2 \pm 0.2$ & $9.6 \pm 0.34$ & $9.8 \pm 0.23$ & $10.3 \pm 1.2$ \\
\hline
\end{tabular}

Composition of vitamin mineral mix (PREMIX PLUS) (quantity/2.5 kg): vitamin A, 5,500,000 IU; vitamin D3, 1,100,000 IU; vitamin B2, $2000 \mathrm{mg}$; vitamin E, $750 \mathrm{mg}$; vitamin K, $1000 \mathrm{mg}$; vitamin B6, $1000 \mathrm{mg}$; vitamin B12, $6 \mu \mathrm{g}$; calcium pantothenate, $2500 \mathrm{mg}$; nicotinamide, $10 \mathrm{~g}$; choline chloride, $150 \mathrm{~g}$; Mn, 27,000 mg; I, $1000 \mathrm{mg}$; Fe, $7500 \mathrm{mg}$; Zn, 5000 mg; Cu, $2000 \mathrm{mg}$; Co, 450 L-lysine, $10 \mathrm{~g}$; DL-methionine, $10 \mathrm{~g}$; selenium, $50 \mathrm{ppm}$ 
taken for mRNA expression studies. All the sampled tissues were kept in RNA later and stored in $-80{ }^{\circ} \mathrm{C}$ for RNA extraction.

Median lethal dose $\left(\mathrm{LD}_{50}\right)$

For determination of $\left(\mathrm{LD}_{50}\right)$ value, 80 fishes from the same stock as the experimental fish were selected which were being reared in similar physicochemical conditions and were fed the experimental control diet (Table 1). A rough idea of the doses to be injected was obtained from the study of Sahu et al. (2011). The bacterial culture was obtained as glycerol and reactivated by immersing in Müeller-Hinton Broth and incubation for $24 \mathrm{~h}$ at $30{ }^{\circ} \mathrm{C}$. The bacteria were plated on Müeller-Hinton Agar by the spread-plate technique to obtain single colony. A single colony was taken and again regrown in Müeller-Hinton Broth for $24 \mathrm{~h}$ at $30{ }^{\circ} \mathrm{C}$. The culture broth was centrifuged at $1006 \times g$ for $10 \mathrm{~min}$. The supernatant was discarded and the pellets were resuspended in sterile phosphate buffer saline (PBS, $\mathrm{pH} \mathrm{7.4)}$ and the OD of the solution was adjusted to $0.50-0.48 \mathrm{~nm}$. This corresponded to a count of $1.79 \times 10^{7}$, confirmed by total plate count. Then the bacterial cells were diluted to get different concentrations required for the experiment. Eighty fish were distributed randomly into eight groups. The fish of seven groups were injected intraperitoneally with $0.1 \mathrm{~mL} / \mathrm{g}$ of American Type Culture Collection (ATCC) 7966 Aeromonas hydrophila bacterial cell suspension at concentrations of $1.1 \times 10^{1}, 1.1 \times 10^{2}, 1.1 \times 10^{3}, 1.1 \times 10^{4}, 1.1 \times 10^{5}, 1.1 \times 10^{6}$ and $1.1 \times 10^{7} \mathrm{cfu} / \mathrm{mL}$, respectively. The control group was injected $0.1 \mathrm{~mL} / \mathrm{g}$ of PBS. The fish were maintained for another $96 \mathrm{~h}$ and were observed regularly for any overt signs of disease including behavioral abnormalities and mortality. In case of mortality, the causative agent was confirmed by re-isolating $A$. hydrophila from the moribund fish. $\mathrm{LD}_{50}$ value was calculated as per the trimmed Spearman-Karber method (Hamilton et al. 1977).

Bacterial challenge study

Following the feeding trial, 30 fish from each treatment group (10 from each replicate) were anesthetized using 2-phenoxy ethanol and subjected to intraperitoneal injection $0.1 \mathrm{~mL} / \mathrm{g}$ of PBS containing A. hydrophila (ATCC 7966) having $1.79 \times 10^{4} \mathrm{cfu} / \mathrm{mL}$. The fish were maintained for another 10 days and were observed regularly for any overt signs of disease including behavioral abnormalities and mortality. In case of mortality, the causative agent was confirmed by re-isolating $A$. hydrophila from the moribund fish. Blood was collected after challenge of $A$. hydrophila (post-challenge) for immunological assays.

Growth study

On the 1st and 60th day of feeding trial, weight measurement was taken using an electronic balance (Citizen, India). The growth performance of fish was evaluated in terms of percentage weight gain (\%), feed conversion ratio (FCR), feed efficiency ratio (FER), specific growth rate (SGR), and protein efficiency ratio (PER) using the following formulae:

$$
\begin{aligned}
& \text { Weight gain }(\%)=[(\mathrm{FW}-\mathrm{IW}) \times 100] / \mathrm{IW}, \\
& \mathrm{FCR}=\text { Feed given }(\mathrm{DW}) / \text { body weight gain }(\mathrm{WW}), \\
& \mathrm{SGR}(\%)=\{[\ln (\mathrm{FW})-\ln (\mathrm{IW})] / N\} \times 100, \\
& \mathrm{PER}=\text { body weight gain }(\mathrm{WW}) / \text { crude protein fed }(\mathrm{DW}),
\end{aligned}
$$

(where FW is the final weight, IW is the initial weight, DW is the dry weight, WW is the wet weight gain, ln is the natural $\log$, and $N$ is the number of cultural days).

RNA extraction and preparation of cDNA

Total RNA from the tissues was extracted using Trizol ${ }^{\mathrm{TM}}$ reagent (Invitrogen Waltham, USA). DNaseI treatment was given to extract RNA using DNaseI, RNase-free kit (Thermo scientific, Waltham, MA, USA) to remove any co-purified genomic DNA. The DNase I treated RNA isolated from different tissues of $L$. rohita 
was analyzed by agarose gel electrophoresis and displayed three distinct bands. The ratio of 28S:18S RNA was similar to 2:1, which indicated that total RNA had good integrity. The OD 260/280 value was found to be 2.0, which confirmed that RNA was highly pure and met the requirements for qRT-PCR. cDNA was synthesized from total RNA $(5 \mu \mathrm{g})$ using RevertAid ${ }^{\mathrm{TM}}$ reverse transcriptase First Strand cDNA Synthesis kit (Thermo scientific, USA) as per the manufacturer's instructions. The OD 260/280 value was found to be 1.8 , which confirmed that cDNA was highly pure and met the requirements for qPCR. Successful amplification of house keeping genes using cDNA as the template further confirmed the quality of cDNA.

Molecular cloning of $\beta$-defensin 1 and hepcidin genes

Primers for $\beta$-defensin 1 and hepcidin (Table 2) were designed based on highly conserved regions of $\beta$ defensin 1 and hepcidin gene from various teleost species available in NCBI using Gene runner software v3.5 (http://www.generunner.net/). PCR amplification was performed in a total volume of $20 \mu \mathrm{L}$ containing $2.5 \mu \mathrm{L}$ Taq buffer $(10 \times), 0.5 \mu \mathrm{L}$ dNTP mix $(10 \mathrm{mM}), 2.5 \mu \mathrm{L} \mathrm{MgCl}_{2}(25 \mathrm{mM}), 1 \mu \mathrm{L}$ each of sense and antisense primers (10 pmol), $1 \mu \mathrm{L}$ of $c D N A, 0.25 \mu \mathrm{L}$ of TaqDNA polymerase $(5 \mathrm{U} / \mu \mathrm{L})$ and $12.25 \mu \mathrm{L}$ of nuclease-free water. Amplification was performed in Takara PCR System (Takara, Japan). The PCR conditions included an initial denaturation at $94{ }^{\circ} \mathrm{C}$ for $4 \mathrm{~min}$, followed by 35 cycles of $94{ }^{\circ} \mathrm{C}$ for $30 \mathrm{~s}, 55^{\circ} \mathrm{C}$ for $45 \mathrm{~s}(\beta$-defensin 1$)$ or $56{ }^{\circ} \mathrm{C}$ for $45 \mathrm{~s}$ (hepcidin) and $72{ }^{\circ} \mathrm{C}$ for $1 \mathrm{~min}$ and a final extension of $10 \mathrm{~min}$ at $72{ }^{\circ} \mathrm{C}$.

The PCR products were separated on $1.5 \%$ agarose gels, the desired DNA fragments were sliced carefully and eluted using QIAquick Gel Extraction Kit (Qiagen) following manufacturer's instructions. The desired DNA fragments were cloned into pTZ57R/T vector and transformed into E. coli DH5 $\alpha$ strain using InsTAclone $^{\mathrm{TM}}$ PCR Cloning Kit (Fermentas, USA) following manufacturer's instructions. After confirmation of positive clones by colony PCR, plasmid DNA was isolated from positive colonies using QIAprep Spin Miniprep Kit (Qiagen, USA), following manufacturer's instructions. The plasmid was quantified using Nanodrop spectrophotometer and visualized on $1 \%$ agarose gel. The samples were sequenced using universal M13 primers and Sanger's sequencing method. The sequences obtained were confirmed using NCBI nBLAST homology tool (http://www.ncbi.nlm.nih.gov/blast).

Non-specific immune parameters

The lysozyme activity level was measured using the turbidimetric assay (Sankaran and Gurnani 1972). In the 96-well U-bottom microtitre plate, $150 \mu \mathrm{L}$ of Micrococcus luteus suspension in phosphate buffer (A450 $=0.5-0.7$ ) was taken and $15 \mu \mathrm{L}$ of serum samples was added. The absorbance was taken immediately at $450 \mathrm{~nm}$ in ELISA reader (BioTek Power Wave 340, India) and the plate was incubated at $25^{\circ} \mathrm{C}$ for $1 \mathrm{~h}$ and final absorbance was taken. This absorbance was compared with standard hen egg white lysozyme of a known activity following the same procedure as above. The activity was expressed as $\mathrm{U} / \mathrm{min} / \mathrm{mg}$ protein. The respiratory burst activity of neutrophils was measured by nitroblue tetrazolium (NBT) assay (Secombes 1990). Fifty microliter of blood was placed into the wells of flat bottom microtitre plates and incubated at $37{ }^{\circ} \mathrm{C}$ for

Table 2 List of primers used for RT-PCR and qPCR expression of defensin and hepcidin genes in Labeo rohita

\begin{tabular}{ll}
\hline Primer name & Primer sequence $5^{\prime}-3^{\prime}$ \\
\hline Carp defensin F & ACTTGTCTTGCTTGTCCT \\
Carp defensin R & ACAGCCTAAGGGTCC \\
Carp hepcidin F & TTCTCACGTGTGGCTCTCG \\
Carp hepcidin R & CAGAATTTGCAGCAGTA \\
Defensin qPCR F & TCTTGCTTGTCCTTGTCGTCTTAG \\
Defensin qPCR R & CCTTGTCTGCAAACTCCAGTGA \\
Hepcidin qPCR F & CGCTTGCGTCCTGAACAATG \\
Hepcidin qPCR F & TTCTCAACGTGTGGCTCTCG \\
Beta-actin F & GCCGAGAGGGAAATTGTCCGTGAC \\
Beta-acin R & TTGCCAATGGTGATGACCTGTCCG \\
\hline
\end{tabular}


$1 \mathrm{~h}$ to facilitate adhesion of cells. Then the supernatant was removed and the loaded wells were washed thrice in phosphate buffer saline (PBS). After washing, $50 \mu \mathrm{l}$ of $0.2 \%$ NBT was added and was incubated for $1 \mathrm{~h}$. The cell was then fixed with $100 \%$ methanol for 2-3 min and was again washed thrice with $30 \%$ methanol. The plates were then air dried. Sixty microlitres of $2 \mathrm{~N}$ potassium hydroxide and $70 \mu \mathrm{L}$ dimethyl sulphoxide were added into each well to dissolve the formazan blue precipitate formed. The OD of the turquoise blue colored solution was then read in ELISA reader (BioTek Power Wave 340, India) at 620 nm. Serum protein was estimated by biuret and BCG dye binding method (Reinhold 1953) using total protein kit (Merck, India). Albumin was estimated by bromocresol green binding method (Doumas et al. 1971) using albumin kit (Merck, India). Globulin was calculated by subtracting albumin values from total serum protein values. A:G ratio was calculated by dividing albumin values by globulin values. Phagocytic activity was determined following the method of Anderson and Siwicki (1995). A sample of $0.1 \mathrm{~mL}$ of serum was taken in wells of microtiter plate and $0.1 \mathrm{~mL}$ of Staphylococcus aureus $\left(1 \times 10^{7}\right.$ cells $)$ suspended in phosphate buffer saline $(\mathrm{pH} 7.2)$, was added and shaken sufficiently. This bacterial serum mixture was incubated at room temperature for 20 min. From this mixture, $5 \mu \mathrm{L}$ was taken on a clean glass slide and a smear was prepared. The smear was air dried and fixed with $95 \%$ of ethanol for $5 \mathrm{~min}$ and air dried once again. The smear was stained with Giemsa stain for $10 \mathrm{~min}$. A total of two hundred haemocytes from each smear were observed under the light microscope and the number of phagocytizing cells and bacteria engulfed by the phagocytes were counted. Phagocytic activity was expressed using the formula:

Phagocytic activity $=($ Number of phagocytizing cells/Total number of phagocyte cells counted $) \times 100$.

Gene expression study using qPCR

Real-time PCR was conducted to determine the mRNA expression levels of $\beta$-defensin 1 and hepcidin. For gene expression studies, tissue samples from three fish from each replicate were selected and pooled. Investigation of gene expression was done using qRT-PCR gene-specific primers with $\beta$-actin gene used as an internal control. Real-time PCR amplifications were carried out in LightCycler ${ }^{\circledR}$ Real-time PCR detection system (Roche, USA). The $25 \mu \mathrm{L}$ reaction mix volume was prepared containing $12.5 \mu \mathrm{L}$ of Maxima ${ }^{\mathrm{TM}} \mathrm{SYBR}$ Green qPCR master mix (Thermo scientific, USA), $0.5 \mu \mathrm{L}$ of $(0.3 \mathrm{pM})$ each gene-specific primer and $2 \mu \mathrm{L}$ (20 ng) of cDNA and $9.5 \mu \mathrm{L}$ of nuclease-free water. The default thermal profile was used for PCR amplification and it consisted of initial denaturation at $95{ }^{\circ} \mathrm{C}$ for $10 \mathrm{~min}$, followed by 40 cycles of denaturation at $95{ }^{\circ} \mathrm{C}$ for $15 \mathrm{~s}$ and annealing and extension at $60{ }^{\circ} \mathrm{C}$ for $1 \mathrm{~min}$. Cycle threshold $\left(C_{\mathrm{t}}\right)$ values were obtained from the exponential phase of PCR amplification, and the expressions of genes were normalized to the expression of $\beta$-actin generating a $\Delta C_{\mathrm{t}}$ value $\left[\left(C_{\mathrm{t}}\right.\right.$ of target gene $)-\left(C_{\mathrm{t}}\right.$ of $\beta$-actin $\left.)\right]$. The relative expression level of the target gene in the treatment group to target gene in the control group was determined using $2^{-\Delta \Delta C_{\mathrm{t}}}$ method proposed by Livak and Schmittgen (2001), which gives the value that corresponds to the $n$-fold difference relative to the control.

Calculation of relative percentage survival

Relative percentage of survival (RPS) versus control was calculated at the end of 14 days of infection using the following formula (Amend 1981):

$$
\mathrm{RPS}=1-\left(S_{\mathrm{T}} / S_{\mathrm{C}}\right) \times 100
$$

where $S_{\mathrm{T}}$ is the percentage of surviving fish in treatment group and $S_{\mathrm{C}}$ is the percentage of surviving fish in control group.

\section{Statistical analysis}

The results of immunological parameters, growth performance and gene expression studies obtained from treatments were tested for statistical significance using one-way analysis of variance (ANOVA) followed by 
Duncan's new multiple range tests using the statistical package, SPSS 16.0. $P<0.05$ was considered as statistically significant.

\section{Results}

Quantification of fucoidan

The L-fucose content of the dialyzed extract was $32 \mathrm{mg} / \mathrm{g}$ dried seaweed powder. This was multiplied by a factor of 1.75 to get the total fucoidan content of $5.6 \mathrm{~g} / 100 \mathrm{~g}$ dried seaweed powder.

Growth parameters

There was no significant difference in the percentage weight gain, specific growth rate, protein efficiency ratio and feed conversion ratio among the different treatment groups (Table 3).

Non-specific immune parameters

In the pre-challenge period, the $2 \%$ FRSE (T2F) group revealed a significantly higher serum lysozyme activity (Fig. 1) compared to other experimental groups, which showed no significant difference among them. The same trend was followed in the post-challenge period. In the pre-challenge study, the control group exhibited the least NBT activity, which was statistically similar to the groups T3S and T4S (Fig. 2). The highest and significantly different activity was found in the T2F group. In the post-challenge study, the highest was found in the T2F group. All other groups showed no significant difference in the NBT activity. In both pre- and postchallenge periods the lowest $A: G$ ratio was observed in the $T 2 F$ group, whereas the highest A:G ratio was observed in the control group (Table 4). In the pre-challenge period, the highest phagocytic activity was found in the T2F group, whereas the least was found in the control group. The same trend was also followed in the post-challenge period (Fig. 3).

Sequence analysis partial $\beta$-defensin 1 and hepcidin genes

The sequence for $\beta$-defensin 1 received was $148 \mathrm{bp}$ long and the sequence of hepcidin was $269 \mathrm{bp}$ long. The nBLAST search in NCBI GenBank database with $L$. rohita partial $\beta$-defensin-1 showed sequence similarity of $100 \%$ with Cyprinus carpio beta defensin-like protein (JF343439.1) and Megalobrama amblycephala $\beta$ defensin 1 mRNA (KC351182.1) followed by 98\% similarity with Danio rerio defensin, beta-like 1 (NM_001081553.1). L. rohita partial hepcidin mRNA sequence showed sequence similarity of $98 \%$ with Cyprinus carpio hepcidin (JX855261.1) and Schizothorax richardsonii hepcidin-like antimicrobial peptide mRNA (KC894741.1) followed by 96\% similarity with Puntius sarana mRNA for hepcidin (FN429020.1). $L$. rohita partial hepcidin and defensin gene sequence was submitted to NCBI GenBank vide accession number KM 040782 and LC 259205, respectively.

Table 3 Growth parameters of different experimental groups fed different experimental diets at the end of the experiment

\begin{tabular}{llllr}
\hline Treatments & Wt. gain $\%$ & SGR & FCR & PER \\
\hline Control & $43.68 \pm 1.37$ & $0.26 \pm 0.01$ & $2.75 \pm 0.08$ & $0.96 \pm 0.02$ \\
T1F & $46.39 \pm 0.68$ & $0.27 \pm 0.03$ & $2.58 \pm 0.04$ & $0.96 \pm 0.01$ \\
T2F & $41.89 \pm 2.04$ & $0.25 \pm 0.01$ & $2.87 \pm 0.14$ & $1.00 \pm 0.05$ \\
T3S & $45.10 \pm 1.02$ & $0.26 \pm 0.001$ & $2.66 \pm 0.06$ & $0.93 \pm 0.02$ \\
T4S & $45.15 \pm 2.00$ & $0.26 \pm 0.01$ & $2.66 \pm 0.12$ & $0.93 \pm 0.04$
\end{tabular}

Mean values $(n=3)$ in the same column with no superscript do not differ significantly $(P<0.05)$. Data were expressed as mean $\pm \mathrm{SE}$

Wt. gain \% weight gain percentage, SGR specific growth rate, FCR feed conversion ratio, PER protein efficiency ratio 


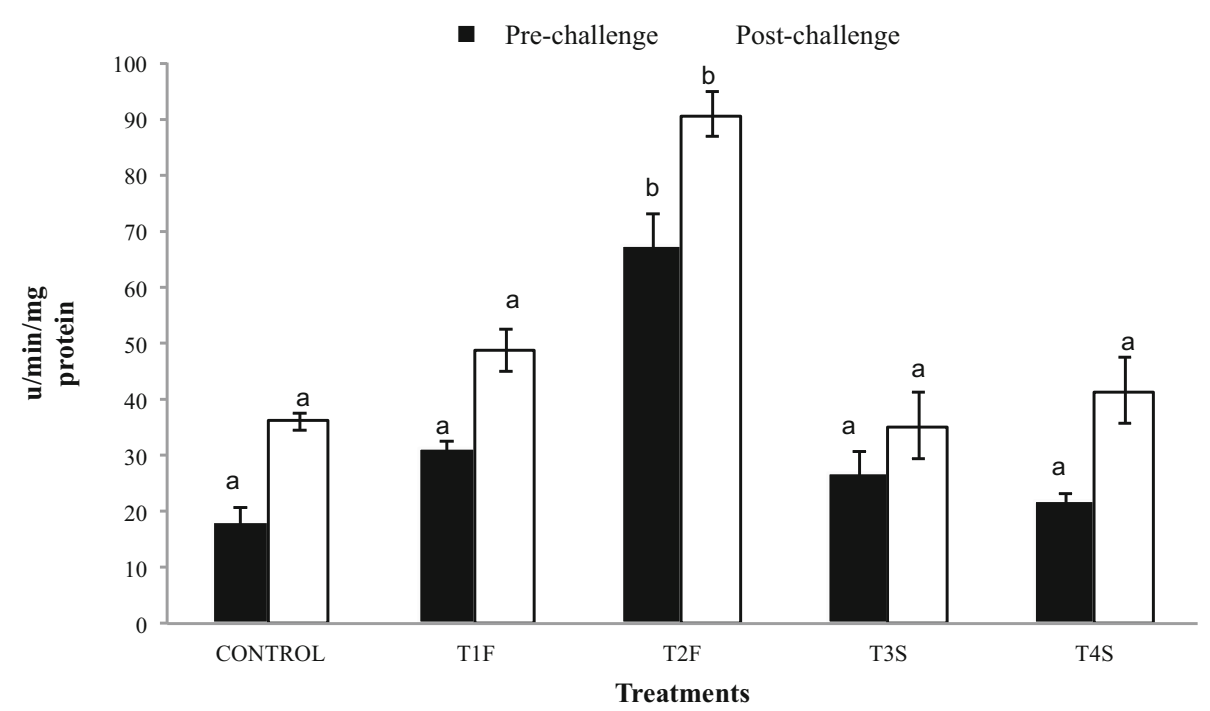

Fig. 1 Pre- and post-challenge serum lysozyme activities of different experimental groups. Mean values $(n=3)$ in the experimental group with different superscripts, $(\mathrm{a}, \mathrm{b})$ differ significantly $(P<0.05)$. Data were expressed as mean $\pm \mathrm{SE}$. Control-0\% FRSE, T1F-1\% FRSE, T2F-2\% FRSE, T3S-3\% seaweed powder, T4S-6\% seaweed powder

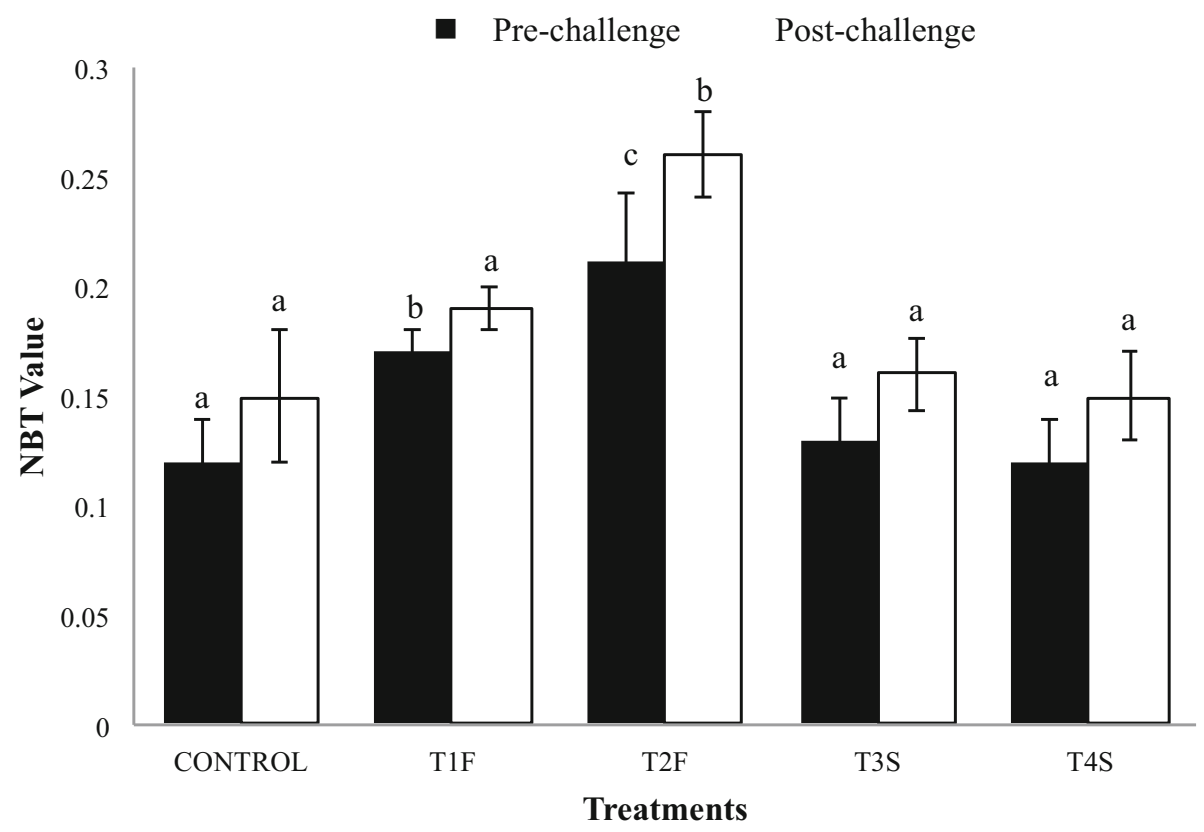

Fig. 2 Pre- and post-challenge NBT values of different experimental groups. Mean values $(n=3)$ in the experimental group with different superscripts $(\mathrm{a}, \mathrm{b}, \mathrm{c})$ differ significantly $(P<0.05)$. Data were expressed as mean $\pm \mathrm{SE}$. Control—0\% FRSE; T1F-1\% FRSE; T2F-2\% FRSE; T3S-3\% seaweed powder; T4S-6\% seaweed powder

Tissue distribution and real-time PCR analysis of the expression levels of $\beta$-defensin 1 and hepcidin

There was a variation in the tissue level expression of $\beta$-defensin 1 and hepcidin in Labeo rohita. Defensin mRNA expression was observed in gill, skin, liver and intestine whereas hepcidin was expressed in liver, kidney, spleen and intestine (Fig. 4). On the 60th day of feeding of experimental diets, the skin tissue of T2F group showed a 7.9-fold increase $(P>0.05)$ in $\beta$-defensin 1 expression compared to the control group (Fig. 5). The expression in the liver was increased 2.1-fold in the T2F group as compared to the control group. A slight but significant $(P>0.05)$ increase of 1.8 -fold was found in the $\beta$-defensin 1 expression of the 


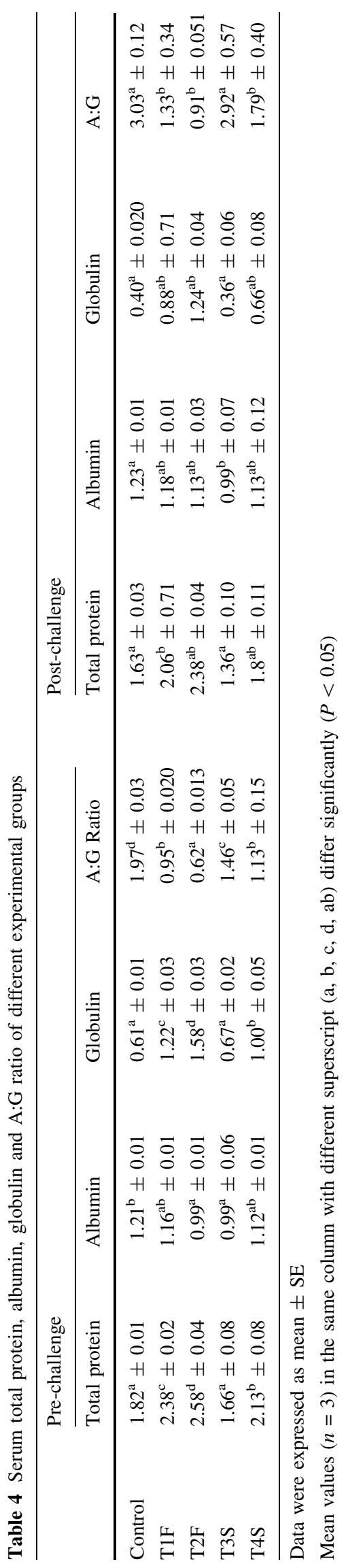




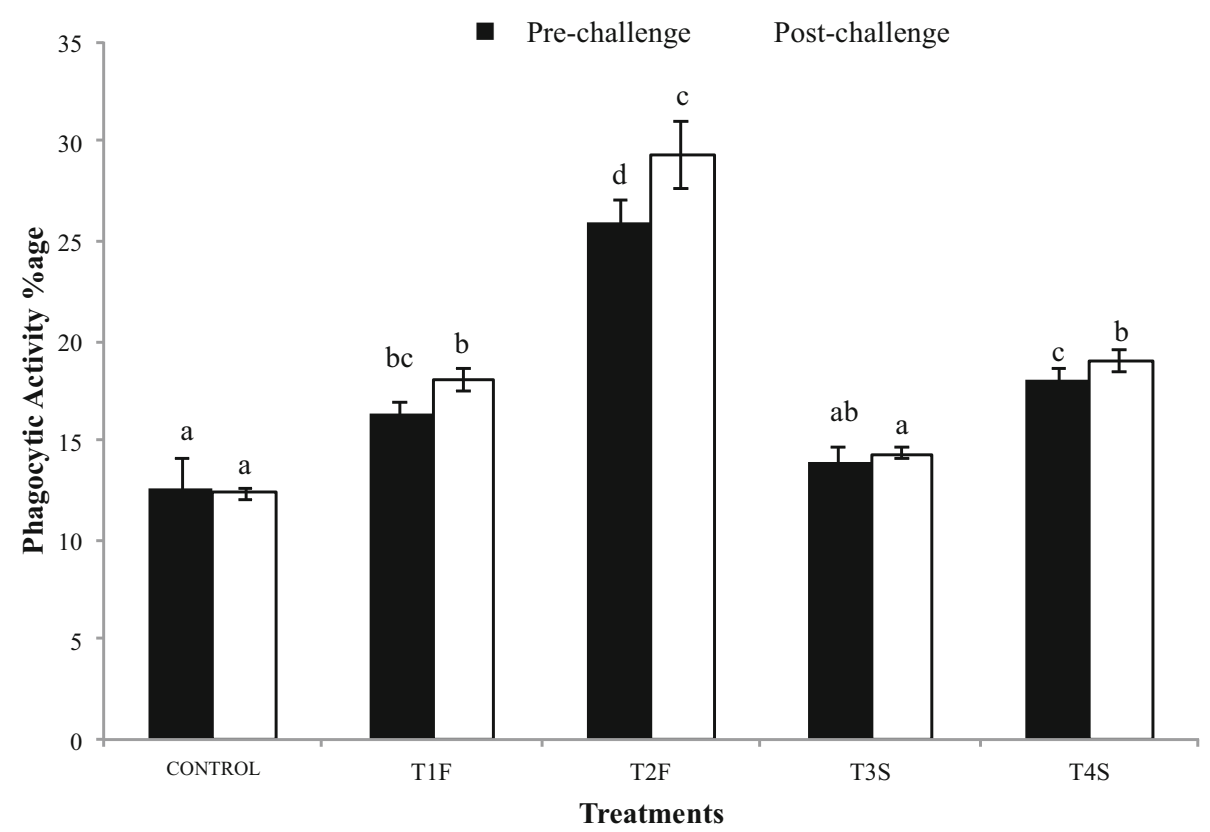

Fig. 3 Pre- and post-challenge phagocytic activity of different experimental groups. Mean values with different superscript (a, b, $\mathrm{c}, \mathrm{d}, \mathrm{ab})$ differ significantly $(P<0.05)$. Data were expressed as mean $\pm \mathrm{SE}, n=3$

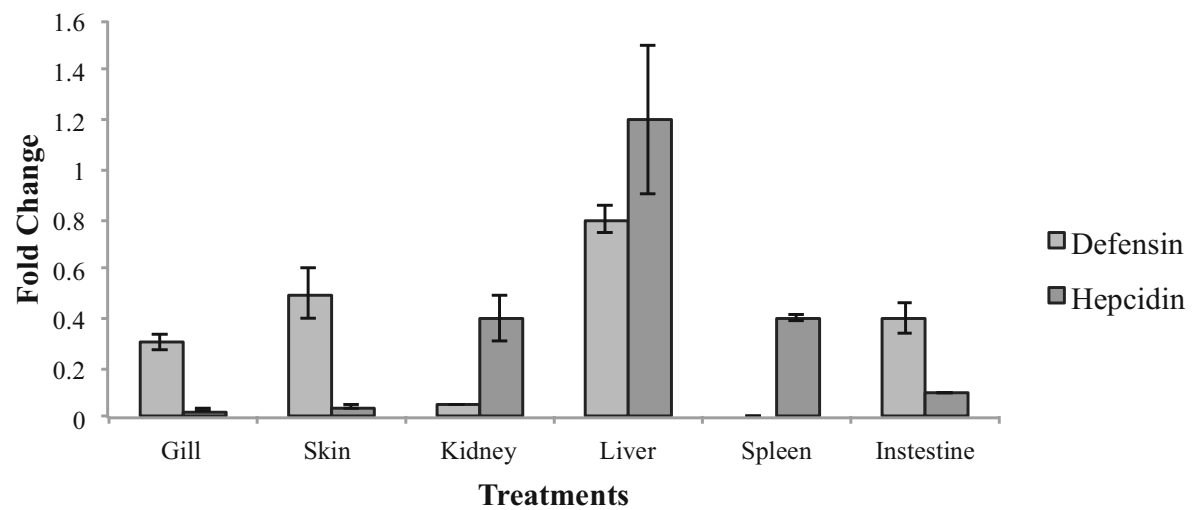

Fig. 4 Distribution of mRNA expression of antimicrobial peptides in different tissues of juvenile Labeo rohita. The relative expression of defensin and hepcidin normalized with beta-actin in samples was calculated using comparative $C_{\mathrm{t}}$ method. The fold change was compared with beta-actin of muscle tissue in which the copy number was considered as onefold. Data for real-time PCR were expressed as mean $\pm \mathrm{SE}(n=3)$

intestine, whereas no significant increase was found in the gill. The crude fucoidan extract fed at dietary level of 1 and 2\% showed a 3.4- and 6.4-fold higher expression of hepcidin in the liver (Fig. 6). Compared to the control group, the expression of hepcidin in the spleen was slightly, but significantly, higher in all the other groups.

$\mathrm{LD}_{50}$ value and challenge study

The $\mathrm{LD}_{50}$ value obtained after 5 days of observation period for the viable cells of A. hydrophila (ATCC 7986) injected to Labeo rohita fingerlings was found to be $1.79 \times 10^{4} \mathrm{cfu} / \mathrm{mL}$. After injecting $0.1 \mathrm{~mL} / \mathrm{g}$ of the same concentration bacteria in the experimental fish, the first mortality was observed at $11 \mathrm{~h}$. At the end of the 14 days challenge period, the highest relative percentage of survival was found in the T2F group, fed $2 \%$ 


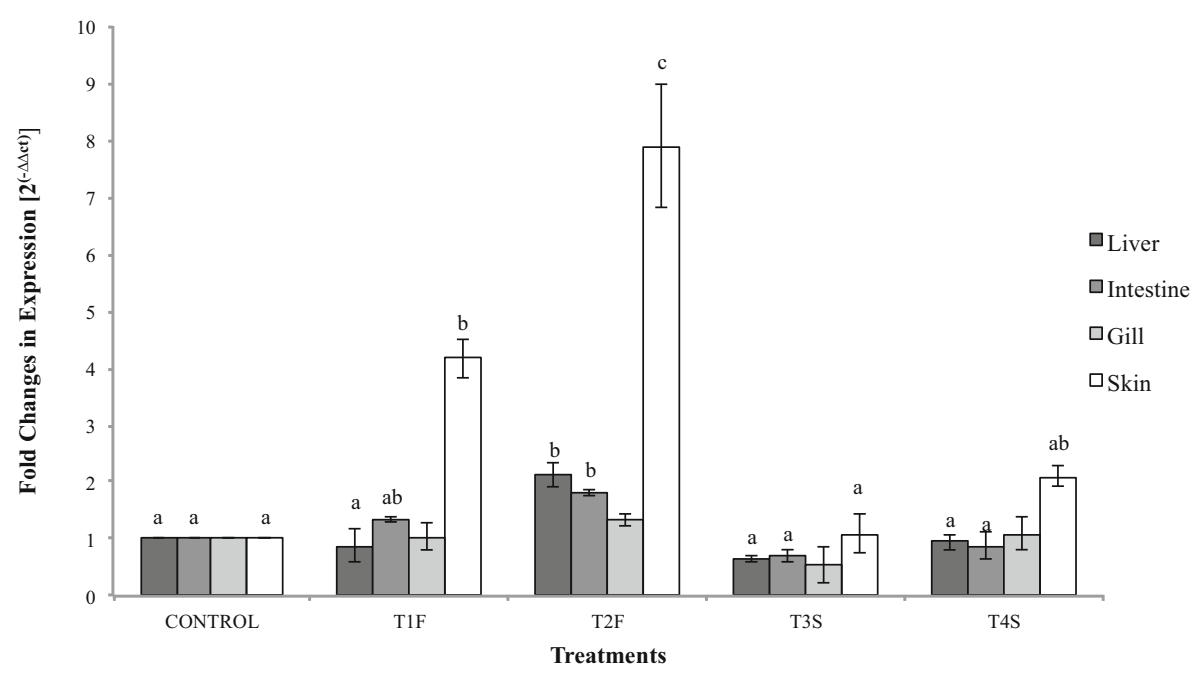

Fig. 5 Relative expression of Labeo rohita defensin mRNA in the liver, intestine, gill and skin after 60 days of experimental feeding regimen. Beta-actin was used as an internal control to calibrate the cDNA template for all samples. The data are presented as a fold increase of normalized mRNA copies in tissues of fish fed with different experimental diets to normalized mRNA copies in the tissues of fish fed with control diet. Data were expressed as mean $\pm \mathrm{SE}, n=3$. Mean values of the same tissue with different superscripts $(\mathrm{a}, \mathrm{b}, \mathrm{ab}$ and $\mathrm{c})$ differ significantly $(P<0.05)$. Mean values of the same tissue with no superscript do not differ significantly $(P<0.05)$

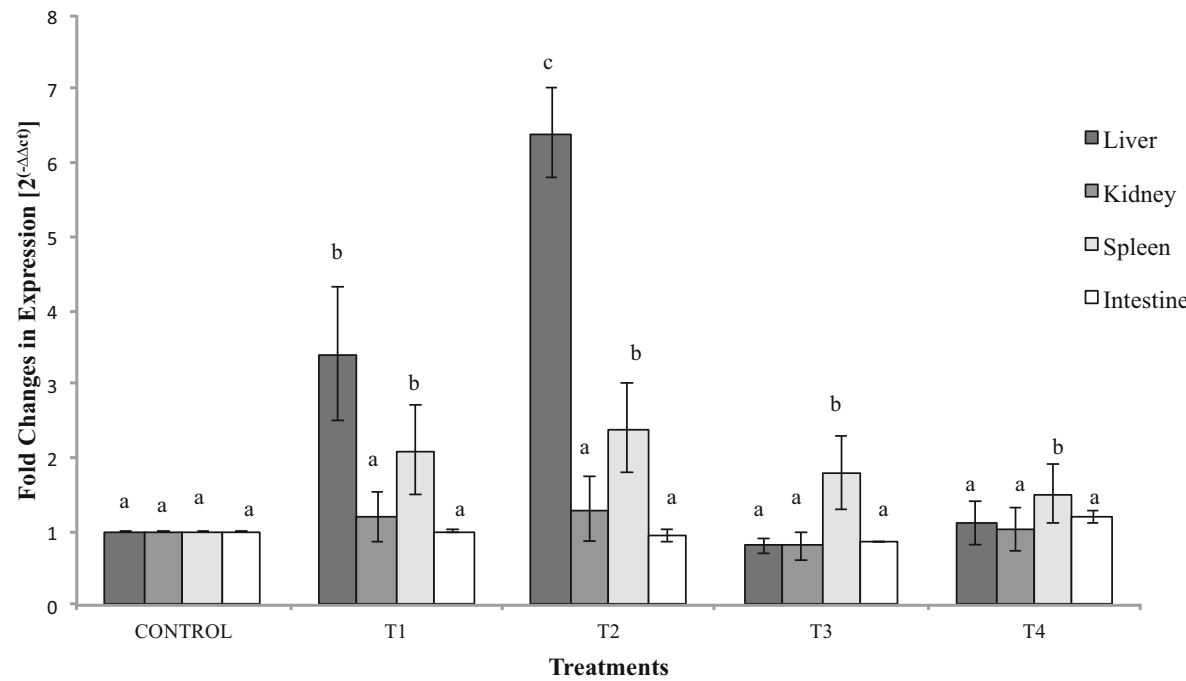

Fig. 6 Relative expression of Labeo rohita hepcidin mRNA in the different tissues after 60 days of experimental feeding regimen. Beta-actin was used as an internal control to calibrate the cDNA template for all samples. The data are presented as a fold increase of normalized mRNA copies in liver of fish fed with different experimental diets to normalized mRNA copies in the liver of fish fed with control diet. Data are expressed as mean $\pm \mathrm{SE}, n=3$. Mean values with different superscripts $(\mathrm{a}, \mathrm{b}$ and $\mathrm{c})$ differ significantly $(P<0.05)$. Mean values of the same tissue with no superscript do not differ significantly

dietary fucoidan (Table 5). The groups fed 3 and 6\% seaweed powder, T3S and T4S, exhibited the lowest relative percentage survival.

\section{Discussion}

The culture conditions, which deviate from the natural habitat, induce stress in fish (Barton and Iwama 1991). Stress increases susceptibility to diseases, possibly due to chronic elevated cortisol levels, causing 
Table 5 Percentage mortality and relative percentage of survival of the different treatment groups after challenge with Aeromonas hydrophila at the end of the experimental trial of 60 days

\begin{tabular}{llc}
\hline Treatments & Percentage mortality & Relative percentage of survival \\
\hline Control & $55.55^{\mathrm{a}} \pm 6.4$ & $00.00 \pm 00.00$ \\
T1F & $40.74^{\mathrm{b}} \pm 3.7$ & $26.66^{\mathrm{b}} \pm 6.66$ \\
T2F & $29.63^{\mathrm{c}} \pm 3.7$ & $46.66^{\mathrm{c}} \pm 6.66$ \\
T3S & $50.00^{\mathrm{a}} \pm 3.2$ & $10^{\mathrm{a}} \pm 5.77$ \\
T4S & $53.70^{\mathrm{a}} \pm 1.8$ & $3.33^{\mathrm{a}} \pm 3.33$ \\
\hline
\end{tabular}

Data of percentage mortality expressed as mean \pm SE $(n=3)$. Relative percentage of survival compared against mean value of percentage mortality of control group $(55.55 \%)$ which is assumed to be $100 \%$. Mean values in the same column with different superscripts $(\mathrm{a}, \mathrm{b}, \mathrm{c})$ differ significantly $(P<0.05)$

immunosuppressive and catabolic actions (Refstie 1977). Although the use of prophylactic or metaphylactic antibiotics is a logical approach to avoid infections, it suffers from certain inherent drawbacks (Hektoen et al. 1995). Immune system of fish can be stimulated through the diet either by providing certain dietary nutrients in excess than the requirements (Pohlenz et al. 2012) or by administration of certain immunostimulant nonnutritive ingredients (Rieder and Samuelsen 2012). However, cost is the major deciding factor for including those ingredients in the feed. In the present study, emphasis was laid on the feasibility and cost effectiveness of the extraction process of fucoidan and the yield was calculated to be $5.6 \%$ in the crude extract. The yield of fucoidan varies widely depending upon the method of extraction employed and also the species of seaweeds (Ale et al. 2012). The present inexpensive method of alcohol water extraction does not involve the use of acid and can be employed for large-scale preparation of fucoidan-rich seaweed extract.

The effect of fucoidan-rich seaweed extract on growth performance of carps has not been studied yet. Fucoidan has shown significant increase in growth performance in aquatic animals (Traifalgar et al. 2010; Immanuel et al. 2012; Tuller et al. 2014; Prabu et al. 2016). We found no significant difference in growth performance of the experimental groups. There are number of reports which suggested that fucoidan is a potential inhibitor of cellular division (Religa et al. 2000; Yoshimoto et al. 2015) and cellular growth in various organisms (Aisa et al. 2004; Haneji et al. 2005; Maruyama et al. 2006; Alekseyenko et al. 2007). These studies indicate that fucoidan may not induce growth performance and hence support our findings. The growth promoting effect of fucoidan in some organisms may be an indirect effect through stress mitigation. However, it remains to be confirmed and needs further research.

The non-specific immune system of fish can respond to external factors (Tort et al. 2003) including dietary compounds (Magnadottir 2010). Respiratory burst (NBT reduction) is an important component of the nonspecific immune system involved in the early eradication of pathogen (Bellavite 1988). Respiratory burst activity in fish may be modulated through production of reactive oxygen species in response to immunostimulants (Liu et al. 2014). Fucoidan-fed fish groups exhibited higher NBT reduction activity of the phagocytes compared to the control and the seaweed fed groups. This indicates that fucoidan boosts the immune system and health status of fish (Yang et al. 2014; Prabu et al. 2016). Phagocytic activity represents an immediate response carried out by the phagocytes to kill the pathogenic bacteria as a part of their defense mechanism (Neumann et al. 2001). It is a key element in host defenses against bacterial infections (Kantari et al. 2008). We found a dose-dependent increase in the phagocytic activity of the macrophages with the highest phagocytic activity observed in the $2 \%$ FRSE treatment, which has also been observed previously by El-Boshy et al. (2014). Lysozyme has a bactericidal effect by destroying cellular walls of bacteria. Lysozyme also stimulates phagocytic activity and participates in the regulation of immune cell differentiation and proliferation (Ghiasi et al. 2010). The dietary FRSE at 2\% dietary level could increase the lysozyme activity of the fish compared to the control groups. Serum lysozyme activity has been found to be responsive to dietary fucoidan (El-Boshy et al. 2014; Prabu et al. 2016). At 2\% dietary FRSE, the A:G ratio in the serum of fish reduced significantly compared to the control. The results indicate that the non-specific immune parameters are stimulated by dietary fucoidan-rich seaweed extract in a dose-dependent manner. It will be interesting to study the possible level of inclusion of fucoidan in the diet of carps providing immunostimulation at the least cost. 
Antimicrobial compounds are important components of the innate immune system and are crucial to host defense. Out of the 2159 antimicrobial peptides identified from animals, 114 have been isolated from fish (The Antimicrobial Peptide Database 2017). Two antimicrobial peptides, $\beta$-defensin 1 and hepcidin were partially characterized from Labeo rohita with sequences of 148 and $269 \mathrm{bp}$, respectively. No study has been carried out to study the tissue level expression of antimicrobial peptides in response to feeding FRSE in fish. Antimicrobial peptides are the primitive components of the innate immune system, known to express in liver skin, gills and gut, (Marel et al. 2012) and act as the first line of defense against the bacterial pathogens. Therefore, expression study of the antimicrobial peptides in such tissues may provide significant information regarding the stimulation of peptide expression by immunostimulants and involvement in defense against bacterial pathogens. We found highest expression of $\beta$-defensin 1 in the skin, followed by the liver, whereas no significant upregulation was observed in the gill. The mechanism of immunostimulation by fucoidan in fish is not clearly known. However, the increased expression of $\beta$-defensin 1 in the skin may be explained on the basis of water-soluble nature of fucoidan and the possibility of interaction of fish with the pellets or with the leachate (Casadei et al. 2013). The expression of $\beta$-defensin 1 in the skin of fish has been induced by pathogenic challenge (Chen et al. 2013) as well as by immunostimulants in fish (Marel et al. 2012). Oral administration of FRSE had significant effect on the $\beta$-defensin 1 mRNA expression in the gut of the fish. The fish gut is a complex of endogenous probiotic bacteria, pathogenic bacteria, mucus, enzyme and bile secretions and the semidigested food. The endogenous probiotic bacteria and the gut mucosa prevent the colonization of the pathogenic bacteria and could also exert immunostimulatory effect on the gut-associated lymphoid system (Picchietti et al. 2007). Thus, the use of immunostimulant may alter the eubiosis of the gut or may stimulate the immune system. The effect of fucoidan on the gut microbiota of teleost fish has not been studied so far. Fucoidan is unique in the sense that it is an immunostimulant-possessing antibacterial property (Zapopozhets et al. 1995). Indeed, it will be interesting to study the interaction of fucoidan on the gut microbiota and its effect on immune system of the fish. Besides $\beta$-defensin 1 , hepcidin is another most studied antimicrobial peptide (Shi and Camus 2006) that has been established as an iron-regulating hormone. For the expression study of hepcidin, the liver tissue was chosen, as it is the main site of expression of hepcidin (Krause et al. 2000). The expression of hepcidin gene in the liver was upregulated almost 6.5 times on the 60th day by feeding 2\% FRSE. Hepcidin expression has been found responsive in different fish species when challenged with lipopolysaccharides (Hirono et al. 2005) and pathogenic bacteria (Wang et al. 2009). Hepcidin also shows inhibiting effect on A. hydrophila (Cai et al. 2012). However, only a limited number of studies have sought to investigate the effect of dietary immunostimulants on the gene expression of hepcidin in teleost fishes (Skov et al. 2012).

A. hydrophila is a Gram-negative, rod-shaped bacteria with single flagellum. Antimicrobial peptides have been shown to be active against Gram-negative bacteria (Hsieh et al. 2010). The mechanisms of multiple antimicrobial peptides have been analyzed and a model, termed the Shai-Matsuzaki-Huang model, has been proposed in which cationic antimicrobial peptides may use their positive charge to bind to the surface anionic membrane components of bacterial cells (Zasloff 2002). This binding is suggested to result in the leakage of bacterial cellular components, thereby killing the bacterial cells. Higher expression of antimicrobial peptides was recorded in the skin, liver and the intestine of $L$. rohita. These tissues are known to be the portal of entry and predilection sites of A. hydrophila in the fish. Therefore, the reduced post-challenge mortality of the fucoidan-fed fish may be attributed to the protection provided by increased expression of antimicrobial peptides and also stimulation of innate immune system.

The activation of antimicrobial peptides gene expression in particular, and the non-specific immune system in general, by feeding sulphated polysaccharides (FRSE) is thought to be mediated primarily through their recognition by specific receptors. The interaction of immunostimulatory polysaccharides with cell receptors may trigger signaling pathways, ultimately leading to induction of gene transcription (Xu et al. 2014). Therefore, it may be assumed that immunostimulatory action of fucoidan in the fish follows the same mechanism as other polysaccharides. However, at present, it remains to be confirmed and requires further research.

Seaweed powder is obtained from drying and pulverizing of the seaweed Sargassum wightii. The seaweed powder is the base material for the extraction of crude fucoidan. In the T3S and T4S group, seaweed powder was mixed with the feed at the rate 3 and 4\%, respectively. Syad et al. (2013) found that Sargassum wightii has a fiber content of $17 \%$ dry weight and crude protein content of $1.4 \mathrm{mg} / \mathrm{g}$ dry weight. This means that the 
chance of any nutritional supplementation of the fish by feeding dry seaweed powder is very meager. Seaweed was included in T3S and T4S to evaluate any effect of dietary fucoidan from the seaweed powder on the fish. The growth performance and immune status and gene expression of antimicrobial peptides in these treatments had no significant difference from the control group. We observed that only fucoidan extracted from the seaweed powder has beneficial effect on fish immunity. Although there is considerable amount of fucoidan in T3S and T4S feeds coming from the seaweed powder, it is possible that seaweed bound fucoidan is in some inactive form and hence unable to incite any response in the fish.

\section{Conclusion}

Careful examination of the changes in genes expression and other immune parameters could reveal the processes that are involved in triggering the immune system of the fish by seaweed compounds. In the present study, we report characterization of two antimicrobial peptide genes $\beta$-defensin 1 and hepcidin with 148 and $269 \mathrm{bp}$, respectively, in L. rohita. Although there was no improvement in the growth of fish due to feeding fucoidan-rich seaweed extract, the expression of hepcidin was significantly upregulated in the liver. $\beta$-defensin 1 expression was also upregulated in the liver, skin and intestine. The non-specific immune parameters also showed response when the fish were fed with fucoidan rich seaweed extract. The post-challenge survival was highest in the FRSE fed groups. It concludes that fucoidan at the dietary level of $2 \%$ is a potential immunostimulant for L. rohita, although it does not have any growth promoting effect. The information generated through this study can be useful for designing studies on farmed fish to demonstrate the suitability of seaweed polysaccharides in preventive health care.

Acknowledgements The authors are grateful to Director, ICAR-Central Institute of Fisheries Education, Mumbai, India, for providing support and facilities to carry out this research. This work is dedicated to late Ms. Pooja Bhatt.

\section{Compliance with ethical standards}

Conflict of interest All authors report no conflict of interest.

Open Access This article is distributed under the terms of the Creative Commons Attribution 4.0 International License (http:// creativecommons.org/licenses/by/4.0/), which permits unrestricted use, distribution, and reproduction in any medium, provided you give appropriate credit to the original author(s) and the source, provide a link to the Creative Commons license, and indicate if changes were made.

\section{References}

Aisa Y, Miyakawa Y, Nakazato T, Shibata H, Saito K, Ikeda Y, Kizaki M (2004) Fucoidan induces apoptosis of human HS-Sultan cells accompanied by activation of caspase-3 and down-regulation of ERK pathways. Am J Hematol 78:7-14. https://doi.org/ 10.1002/ajh.20182

Ale MT, Mikkelsen JD, Meyer AS (2012) Designed optimization of a single-step extraction of fucose-containing sulfated polysaccharides from Sargassum sp. J Appl Phycol 24:715-723. https://doi.org/10.1007/s10811-011-9690-3

Alekseyenko TV, Zhanayeva SY, Venediktova AA, Zvyagintseva TN, Kuznetsova TA, Besednova NN, Korolenko TA (2007) Antitumor and antimetastatic activity of fucoidan, a sulfated polysaccharide isolated from the Okhotsk sea Fucus evanescens brown alga. Bull Exp Biol Med 143:730-732. https://doi.org/10.1007/s10517-007-0226-4

Álvarez CA, Guzmán F, Cárdenas C, Marshall SH, Mercado L (2014) Antimicrobial activity of trout hepcidin. Fish Shellfish Immunol 41:93-101. https://doi.org/10.1016/j.fsi.2014.04.013

Amend DF (1981) Potency testing of fish vaccines. In: Anderson DP, Hennessen H (eds) Fish biologies: serodiagnostics and vaccines, vol 49. Development in biological standardization. Karger, Basel, pp 447-454

Anderson DP, Siwicki AK (1995) Basic haematology and serology for fish health programmes. In: Shharif M, Arthur JR, Subashinge RP (eds) Diseases in Asian aquaculture II. Fish Health Section, Asian Fisheries Society, Manilla, pp 185-202

Angulo FJ, Nargund VN, Chiller TC (2004) Evidence of an association between use of anti-microbial agents in food animals and anti-microbial resistance among bacteria isolated from humans and the human health consequences of such resistance. J Vet Med 51:374-379. https://doi.org/10.1111/j.1439-0450.2004.00789.x

Arunkumar K, Selvapalam N, Rengasamy R (2005) The antibacterial compound sulphoglycerolipid 1-0 palmitoyl-3-0(6'-sulpho$\alpha$-quinovopyranosyl)-glycerol from Sargassum wightii Greville (Phaeophyceae). Bot Mar 48:441-445. https://doi.org/10. $1515 /$ bot.2005.058 
Barton BA, Iwama GK (1991) Physiological changes in fish from stress in aquaculture with emphasis on the response and effects of corticosteroids. Annu Rev Fish Dis 1:3-26. https://doi.org/10.1016/0959-8030(91)90019-G

Bellavite P (1988) The superoxide-forming enzymatic system of phagocytes. Free Radic Biol Med 4:225-261. https://doi.org/10. 1016/0891-5849(88)90044-5

Cai L, Cai JJ, Liu HP, Fan DQ, Peng H, Wang KJ (2012) Recombinant medaka (Oryzias melastigmus) pro-hepcidin: multifunctional characterization. Comp Biochem Physiol B 161:140-147. https://doi.org/10.1016/j.cbpb.2011.10.006

Camus AC, Durborow RM, Hemstreet WG, Thune RL, Hawke JP (1998) Aeromonas bacterial infections-motile aeromonad septicemia. SRAC Publ 478:1-4

Casadei E, Bird S, Vecino JLG, Wadsworth S, Secombes CJ (2013) The effect of peptidoglycan enriched diets on antimicrobial peptide gene expression in rainbow trout (Oncorhynchus mykiss). Fish Shellfish Immunol 34:529-537. https://doi.org/10. 1016/j.fsi.2012.11.027

Chen Y, Zhao H, Zhang X, Luo H, Xue X, Li Z, Yao B (2013) Identification, expression and bioactivity of Paramisgurnus dabryanus b-defensin that might be involved in immune defense against bacterial infection. Fish Shellfish Immunol 35:399-406. https://doi.org/10.1016/j.fsi.2013.04.049

Chotigeat W, Tongsupa S, Supamataya K, Phongdara A (2004) Effect of fucoidan on disease resistance of black tiger shrimp. Aquaculture 233:23-30. https://doi.org/10.1016/j.aquaculture.2003.09.025

Cuesta A, Meseguer J, Esteban MA (2011) Molecular and functional characterization of the gilthead seabream beta-defensin demonstrate its chemotactic and antimicrobial activity. Mol Immunol 48:1432-1438. https://doi.org/10.1016/j.molimm.2011. 03.022

Defoirdt T, Sorgeloos P, Bossier P (2011) Alternatives to antibiotics for the control of bacterial disease in aquaculture. Curr Opin Microbiol 14:251-258. https://doi.org/10.1016/j.mib.2011.03.004

Deivasigamani B, Subramanian V (2016) Applications of immunostimulants in aquaculture: a review. Int J Curr Microbiol App Sci 5:447-453

Doumas BT, Watson W, Biggs HG (1971) Albumin standards and measurement of serum albumin with bromocresol green. Clin Chim Acta 31:87-96

Dubois M, Gilles KA, Hamilton JK, Rebers PA, Smith F (1956) Colorimetric method for determination of sugars and related substances. Anal Chem 28:350-356. https://doi.org/10.1021/ac60111a01

El-Boshy M, El-Ashram A, Risha E, Abdelhamid F, Zahran E, Gab-Alla A (2014) Dietary fucoidan enhance the non-specific immune response and disease resistance in African catfish, Clarias gariepinus, immunosuppressed by cadmium chloride. Vet Immunol Immunopathol 15:168-173. https://doi.org/10.1016/j.vetimm.2014.10.001

Falco A, Chico V, Marroqui L, Perez L, Coll JM, Estepa A (2008) Expression and antiviral activity of a beta-defensin-like peptide identified in the rainbow trout (Oncorhynchus mykiss) EST sequences. Mol Immunol 45:757-765. https://doi.org/10.1016/j. molimm.2007.06.358

Ghiasi F, Mirzargar SS, Badakhshan H, Shamsi S (2010) Effects of low concentration of cadmium on the level of lysozyme in serum, leukocyte count and phagocytic index in Cyprinus carpio under the wintering conditions. J Fish Aquat Sci 5:113-119. https://doi.org/10.3923/jfas.2010.113.119

Gong L, Wang H, Deng L (2014) Molecular characterization, phylogeny and expression of a hepcidin gene in the blotched snakehead Channa maculate. Dev Comp Immunol 44:1-11. https://doi.org/10.1016/j.dci.2013.11.007

Hamilton MA, Russo RC, Thurston RV (1977) Trimmed Spearman-Karber method for estimating median lethal concentrations in toxicity bioassays. Environ Sci Technol 11:714-719. https://doi.org/10.1021/es60130a004

Haneji K, Matsuda T, Tomita M, Kawakami H, Ohshiro K, Uchihara J, Masuda M, Takasu N, Tanaka Y, Ohta T, Mori N (2005) Fucoidan extracted from Cladosiphon okamuranus Tokida induces apoptosis of human T-cell leukemia virus type 1-infected T-cell lines and primary adult T-cell leukemia cells. Nutr Cancer 52:189-201. https://doi.org/10.1207/s15327914nc5202_9

Hektoen H, Berge JA, Hormazabal V, Yndestad M (1995) Persistence of antibacterial agents in marine sediments. Aquaculture 133:175-184. https://doi.org/10.1016/0044-8486(94)00310-K

Hirono I, Hwang JY, Ono Y, Kurobe T, Ohira T, Nozaki R, Aoki T (2005) Two different types of hepcidins from the Japanese flounder Paralichthys olivaceus. FEBS J 272:5257-5264. https://doi.org/10.1111/j.1742-4658.2005.04922.x

Hsieh JC, Pan CY, Chen JY (2010) Tilapia hepcidin (TH)2-3 as a transgene in transgenic fish enhances resistance to Vibrio vulnificus infection and causes variations in immune-related genes after infection by different bacterial species. Fish Shellfish Immunol 29:430-439. https://doi.org/10.1016/j.fsi.2010.05.001

Huys G, Rhodes G, McGann P, Denys R, Pickup R, Hiney M, Smith P, Swings J (2000) Characterization of oxytetracyclineresistant heterotrophic bacteria originating from hospital and freshwater fish farm environments in England and Ireland. Syst Appl Microbiol 23:599-606. https://doi.org/10.1016/S0723-2020(00)80036-3

Immanuel G, Sivagnanavelmurugan M, Marudhupandi T, Radhakrishnan S, Palavesama A (2012) The effect of fucoidan from brown seaweed Sargassum wightii on WSSV resistance and immune activity in shrimp Penaeus monodon. Fish Shellfish Immunol 32:551-564. https://doi.org/10.1016/j.fsi.2012.01.003

Kantari C, Pederzoli-Ribeil M, Witko-Sarsat V (2008) The role of neutrophils and monocytes in innate immunity. Contrib Microbiol 15:118-146

Kitikiew S, Chen J, Putra D, Lin Y, Yeh S, Liou C (2013) Fucoidan effectively provokes the innate immunity of white shrimp Litopenaeus vannamei and its resistance against experimental Vibrio alginolyticus infection. Fish Shellfish Immunol 34:280-290. https://doi.org/10.1016/j.fsi.2012.11.016

Krause A, Neitz S, Magert HJ, Schulz A, Forssmann WG, Schulz-Knappe P, Adermann K (2000) LEAP-1, a novel highly disulfide-bonded human peptide, exhibits antimicrobial activity. FEBS Lett 480:147-150. https://doi.org/10.1016/S00145793(00)01920-7 
Liu L, Zhou Y, Zhao X, Wang H, Wang L, Yuan G, Asim M, Wang W, Zeng L, Liu X, Lin L (2014) Oligochitosan stimulated phagocytic activity of macrophages from blunt snout bream (Megalobrama amblycephala) associated with respiratory burst coupled with nitric oxide production. Dev Comp Immunol 47:17-24. https://doi.org/10.1016/j.dci.2014.06.005

Livak KJ, Schmittgen TD (2001) Analysis of relative gene expression data using real-time quantitative PCR and the $2^{-\Delta \Delta C_{\mathrm{T}}}$ method. Methods 25:402-408. https://doi.org/10.1006/meth.2001.1262

Magnadottir B (2010) Immunological control of fish diseases. J Mar Biotechnol 12:361-379. https://doi.org/10.1007/s10126-0109279-x

Marel M, Adamek M, Gonzalez S, Frost P, Rombout J, Wiegertjes G, Savelkoul H, Steinhagen D (2012) Molecular cloning and expression of two defensin and two mucin genes in common carp (Cyprinus carpio L.) and their up-regulation after $\beta$-glucan feeding. Fish Shellfish Immunol 32:494-501. https://doi.org/10.1016/j.fsi.2011.12.008

Maruyama H, Tamauchib H, lizuka M, Nakano T (2006) The role of NK cells in antitumor activity of dietary fucoidan from Undaria pinnatifida Sporophylls (Mekabu). Planta Med 72:1415-1417. https://doi.org/10.1055/s-2006-951703

Neumann NF, Stafford JL, Barreda D, Ainsworth AJ, Belosevic M (2001) Antimicrobial mechanisms of fish phagocytes and their role in host defense. Dev Comp Immunol 25:807-825. https://doi.org/10.1016/S0145-305X(01)00037-4

Picchietti S, Mazzini M, Taddei AR, Renna R, Fausto AM, Mulero V, Carnevali O, Cresci A, Abelli L (2007) Effects of administration of probiotic strains on GALT of larval gilthead seabream: immunohistochemical and ultrastructural studies. Fish Shellfish Immunol 22:57-67. https://doi.org/10.1016/j.fsi.2006.03.009

Plumb JA (1999) Overview of warm water fish diseases. J Appl Aquac 2:1-10. https://doi.org/10.1300/J028v09n02_01

Pohlenz C, Buentello A, Mwangi W, Gatlin DM (2012) Arginine and glutamine supplementation to culture media improves the performance of various channel catfish immune cells. Fish Shellfish Immunol 32:762-768. https://doi.org/10.1016/j.fsi.2012. 01.029

Poobalane S, Thompson KD, Diab A, Ardó L, Jeney G, Adams A (2008) Protein expression by Aeromonas hydrophila during growth in vitro and in vivo. Microb Pathog 45:60-69. https://doi.org/10.1016/j.micpath.2008.03.001

Prabu DL, Sahu NP, Pal AK, Dasgupta S, Narendra A (2016) Immunomodulation and interferon gamma gene expression in sutchi cat fish, Pangasianodon hypophthalmus: effect of dietary fucoidan rich seaweed extract (FRSE) on pre and post-challenge period. Aquac Res 47:199-218. https://doi.org/10.1111/are.12482

Refstie T (1977) Effect of density on growth and survival of rainbow trout. Aquaculture 11:329-334. https://doi.org/10.1016/ 0044-8486(77)90082-5

Reinhold JG (1953) Manual determination of serum total protein, albumin and globulin fraction by Biuret method. In: Reiner M (ed) Standard method of clinical chemistry. Academic Press, New York, p 88

Religa P, Kazi M, Thyberg J, Gaciong Z, Swedenborg J, Hedin U (2000) Fucoidan inhibits smooth muscle cell proliferation and reduces mitogen-activated protein kinase activity. Eur J Vasc Endovasc Surg 20:419-426. https://doi.org/10.1053/ejvs.2000. 1220

Rieder A, Samuelsen AB (2012) Do cereal mixed-linked beta-glucans possess immune-modulating activities? Mol Nutr Food Res 56:536-547. https://doi.org/10.1002/mnfr.201100723

Robar N, Burness G, Murray DL (2010) Tropics, trophics and taxonomy: the determinants of parasite-associated host mortality. Oikos 119:1273-1280. https://doi.org/10.1111/j.1600-0706.2009.18292.x

Roberts RJ (1993) Motile aeromonad septicaemia. In: Inglis V, Roberts RJ, Bromage NR (eds) Bacterial diseases of fish. Blackwell Scientific Publications, London, pp 143-157

Sahu I, Das BK, Marhual N, Samanta M, Mishra BK, Eknath AE (2011) Toxicity of crude extracellular products of Aeromonas hydrophila on Rohu, Labeo rohita (Ham.). Indian J Microbiol 51:515-520

Sankaran K, Gurnani S (1972) On the variation in the catalytic activity of lysozyme in fishes. Indian J Biochem Biophys 9:162-165

Secombes CJ (1990) Isolation of salmonid macrophages and analysis of their killing activity. In: Stolen JS, Anderson DP, Robertson BS, van Muiswinkel WB (eds) Techniques in fish immunology. SOS Publications, Fair Haven, pp 137-154

Shi J, Camus AC (2006) Hepcidins in amphibians and fishes: antimicrobial peptides or iron-regulatory hormones? Dev Comp Immunol 30:746-755. https://doi.org/10.1016/j.dci.2005.10.009

Skov J, Kania PW, Holten-Andersen L, Fouz B, Buchmann K (2012) Immunomodulatory effects of dietary $\beta$-1,3-glucan from Euglena gracilis in rainbow trout (Oncorhynchus mykiss) immersion vaccinated against Yersinia ruckeri. Fish Shellfish Immunol 33:111-120. https://doi.org/10.1016/j.fsi.2012.04.009

Smith VJ, Desbois AP, Dyrynda EA (2010) Conventional and unconventional antimicrobials from fish, marine invertebrates and micro-algae. Mar Drugs 8:1213-1262. https://doi.org/10.3390/md8041213

Sørum H (2006) Antimicrobial drug resistance in fish pathogens. In: Aarestrup FM (ed) Antimicrobial resistance in bacteria of animal origin. American Society for Microbiology Press, Washington, DC, pp 213-238

Syad AN, Shunmugiah KP, Kasi PD (2013) Seaweeds as nutritional supplements: analysis of nutritional profile, physicochemical properties and proximate composition of G. acerosa and S. wightii. Biomed Prev Nutr 3:139-144

The Antimicrobial Peptide Database (2017). http://aps.unmc.edu/AP/main.php. Accessed 27 Dec 2017

Tort L, Balasch JC, Mackenzie S (2003) Fish immune system. A crossroads between innate and adaptive responses. Immunologia 22:277-286. http://www.inmunologia.org/Upload/Articles/6/0/602.pdf

Traifalgar RF, Kira H, Tung HT, Michael FR, Lainig A, Yokoyama S, Ishikawa M, Koshio S, Serrano AE, Corre V (2010) Influence of dietary fucoidan supplementation on growth and immunological response of juvenile Marsupenaeus japonicas. J World Aquac Soc 41:235-244. https://doi.org/10.1111/are.12029

Tuller J, Santis CD, Jerry DR (2014) Dietary influence of Fucoidan supplementation on growth of Lates calcarifer (Bloch). Aquac Res 45:749-754. https://doi.org/10.1111/are.12029 
Wang KJ, Cai JJ, Cai L, Qu HD, Yang M, Zhang M (2009) Cloning and expression of a hepcidin gene from a marine fish (Pseudosciaena crocea) and the antimicrobial activity of its synthetic peptide. Peptides 30:638-646. https://doi.org/10.1016/ j.peptides.2008.12.014

Xu W, Faisal M (2010) Defensin of the zebra mussel (Dreissena polymorpha): molecular structure, in vitro expression, antimicrobial activity, and potential functions. Mol Immunol 47:2138-2147. https://doi.org/10.1016/j.molimm.2010.01.025

Xu X, Yan H, Tang J, Chen J, Zhang X (2014) Polysaccharides in Lentinus edodes: isolation, structure, immunomodulating activity and future prospective. Crit Rev Food Sci 54:474-487. https://doi.org/10.1016/j.cbpb.2010.11.003

Yang Q, Yang R, Li M, Zhou Q, Liang X, Elmada ZC (2014) Effects of dietary fucoidan on the blood constituents, anti-oxidation and innate immunity of juvenile yellow catfish (Pelteobagrus fulvidraco). Fish Shellfish Immunol 41:264-270. https://doi. org/10.1016/j.fsi.2014.09.003

Yoshimoto M, Higaki K, Nanba E, Ikeguchi M (2015) Anti-proliferation activity of fucoidan in MKN45 gastric cancer cells and downregulation of phosphorylated ASK1, a cell cycle-regulated kinase. Yogana Acta Medica 58:1-7

Zapopozhets TS, Besednova NN, Loenko I (1995) Antibacterial and immunomodulating activity of fucoidan. Ministerstvo meditsinskoi i mikrobiologicheskoi promyshlennosti SSSR 40:9-13

Zasloff M (2002) Antimicrobial peptides of multicellular organisms. Nature 415:389-395. https://doi.org/10.1007/s10811-0079303-3

Zubia M, Deslandes CP (2008) Alginate, mannitol, phenolic compounds and biological activities of two range- extending brown algae, Sargassum mangarevense and Turbinaria ornata (Phaeophyta: Fucales), from Tahiti (French Polynesia). J Appl Phycol 20:1033-1043. https://doi.org/10.1007/s10811-007-9303-3

\section{Publisher's Note}

Springer Nature remains neutral with regard to jurisdictional claims in published maps and institutional affiliations. 